\title{
PHYSICAL EDUCATION CLASSES WITH THE SCHOOLGIRLS OF BIAŁA PODLASKA SCHOOLS
} Physical education of schoolgirls

\author{
BARBARA BERGIER ${ }^{1}$, AGATA FLISIAK, MAGDALENA FLISIAK \\ ${ }^{1}$ Pope John Paul II State School of Higher Education in Biała Podlaska, Poland
}

\author{
Mailing address: Barbara Bergier, Państwowa Szkoła Wyższa, ul. Sidorska 95/97, 21-500 Biała Podlaska, \\ Poland, tel: +48 83 3449904, e-mail: b.bergier@dydaktyka.pswbp.pl
}

\begin{abstract}
Introduction. The neglect of the needs and potential of the schoolgirls and the dismissive attitude of the teachers towards the pupils and the PE classes are the main causes of the schoolgirls' reluctance to attend the classes and also their lack of propensity towards physical activity in general. Studies of child and youth opinions towards the PE classes show that a number of factors are to be taken into account. The aim of the paper was to ascertain the opinions of the survey participants towards the realized and model PE class and also to ascertain effective ways of pursuing the PE curricula for girls. The article reveals factors discouraging the schoolgirls and reducing their expectations as far as PE classes are concerned. Material and methods. The material for the study were 314 schoolgirls and 51 teachers from Biała Podlaska elementary, middle and high schools. The paper was based on the study conducted with analysis of a questionnaire form and a survey. The survey was conducted in April, 2011. Results. The information obtained from the questionnaires that were filled in by the schoolgirls were compiled and compared with the data from the surveys given by the teachers working with the schoolgirls. Conclusions. Both the girls and the teachers have a positive attitude towards the PE classes, whilst observing a number of perceived faults. Criticism was aimed at a lack of variety in the classes and that the needs, potential and interests of the girls were not taken into account and also the lack of involvement of the girls in the process of planning and pursuing the classes. The girls responded positively to the 2009 education reform proposals. The PE teachers also endorsed the proposals.
\end{abstract}

Key words: PE class, schoolgirls, adolescence, PE teachers

\section{Introduction}

The most important goal of physical education is to shape a personal pattern of a wise, fit, resourceful person who is able to be happy, care for their health and function creatively both now and in future [1].

PE classes enrich pupils with everyday values such as health, honesty, conscientiousness, responsibility, honor, self-control, ability to forgive, obedience, self-reliance, patience, kindness, perseverance, politeness, punctuality, respect, savoir-faire, loyalty and self confidence. Through group activities, with proper communication, the classes allow the pupils to adopt social values. Physical education is a medium for the values based on national tradition, law and order, patriotism, sovereignty, freedom, tolerance, justice, solidarity, social equity, respect for human rights and their dignity [2].

Physical activity is of great importance for the normal psycho-physical development of children and youth. It brings about the increased secretion of endorphin, the hormone of happiness, which makes the person feel better, reduces anxiety, improves the self-esteem and oxygenates the brain, which itself brings about an improvement in concentration and mental processes. Physical activity is a vital psycho-therapeutic through tension relief and disposal of negative emotions.

Despite a number of values provided by PE classes, the activities are underestimated and neglected. The school physical education is worsened by the competitiveness of other activities
(IT classes, art, language classes) and a decrease in the authority of a PE teacher ensuing, in many countries, from the insufficient professional preparation and low commitment to work. This has resulted in the reduction of the number of PE classes being held, as a less important subject (in some countries it was suggested that the classes be removed completely). The classes are rarely subject to control and the teachers themselves neglect their professional self-betterment. It is hard to expect major changes and successes in the field of physical education because the foundations laid at the stage of integrated training by incompetent teachers are not stable nor permanent. It should not be taken into account that the attitudes, abilities and knowledge on physical culture developed at a later stage of education will become habitual and go deep in the conscience of children and youth. The situation is additionally complicated by the lack of necessary weekly obligatory PE classes, especially at the integrated education stage [3].

The attitude of students to the physical culture is affected by a number of factors, such as relations in the peer group, competition on different planes of activity (including sports), emotional attitude, teacher-student relations, sports facilities, system of assessment [4, 5, 6].

A modern education program is fulfilled with creative methods, taking into account the subjectivity of the students, their needs, potential, interests and shaping their self-reliance as the preparation for life-long physical self-education. Highlighting the attractiveness of exercise is particularly vital in the case of 
adolescent schoolgirls. The basis of the new teaching is the teacher being both a pedagogue and a true friend. The teachers, students, parents and the local community should be involved in the process of shaping physical culture [7,8]. The shaping of versatile students' personality and raising them to be creative members of society should be entrusted to the teachers, having inventive methods of teaching, for whom the job is not only a professional duty but also a way to express themselves and satisfy their aspirations and needs [9]. Pedagogic competence is an expression of the teacher's personality and allows us to look examine potential and effectiveness [10]. Among the fundamental teacher's activities the following should be mentioned: the pursuit of actions leading to the individualization of the physical-education process, maintaining a proper level of communication and cooperation with the students, based on security and partnership. The esthetic setting of the class is especially important in the case of girls. The teacher's outfit, slim and fit body, inspires schoolgirls to work on their look and fitness. The model of a PE teacher that all the pedagogues should aspire to should be based on qualities such as comprehension of the developmental needs of the children and youth, subjective treatment of the student, openness, respect, friendliness, high level of fitness, intelligence, consistence, responsibility and empathy [11, 12].

The main aim of the paper was to understand the factors discouraging schoolgirls aged 10-18 from participating in PE classes and working out the guidelines on a model PE class, drawing on the opinion of the schoolgirls.

\section{Material and methods}

314 schoolgirls aged 10-18, from the sixth form of elementary school, the second form of middle school and the second form of high school from 14 Biała Podlaska schools (5 elementary ones, 4 middle ones, and 5 high ones) as well as $51 \mathrm{PE}$ teachers working with the schoolgirls in the institutions, participated in the study. The diagnostic survey method was used in the study, part of which comprised questionnaires and surveys.

\section{Results}

An analysis of the material gathered proved that, despite the positive attitude of the survey participants towards PE classes, they had numerous reservations about the classes. The girls were critical about the teachers' attitude, though the class model proposed by the schoolgirls and the teachers were similar. The study proved that the PE teachers failed to adjust the curriculum to the current needs of the girls ensuing from their psychophysical development and interests.

Some of the girls consider the class to be a joyful and integrating lesson, restoring their self-confidence, whereas the middle-school students and high-school students stated that the class was monotonous and made them feel tired and apathetic. If PE classes were not obligatory the majority of participants would attend them "from time to time", except for the elementary schoolgirls, half of whom declared systematic attendance in the activities (Fig.1).

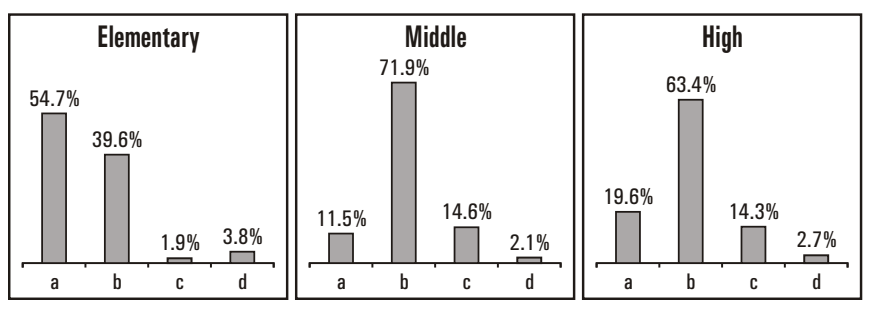

a) I would attend systematically, b) I would attend from time to time, c) I would not attend, d) no answer

Figure 1. The attendance of the girls in PE classes if they were not obligatory

The Biała Podlaska PE teachers displayed a fairly positive attitude to their classes. The majority of them systematically prepared to follow the curriculum and only allowed spontaneous situations to happen in their classes on occasion. The classes were dominated by classical teaching methods, didactic forms and means, minimizing the use of inventive pedagogical methods. For most of the survey participants the work remained the source of income and everyday duty (Fig. 2).
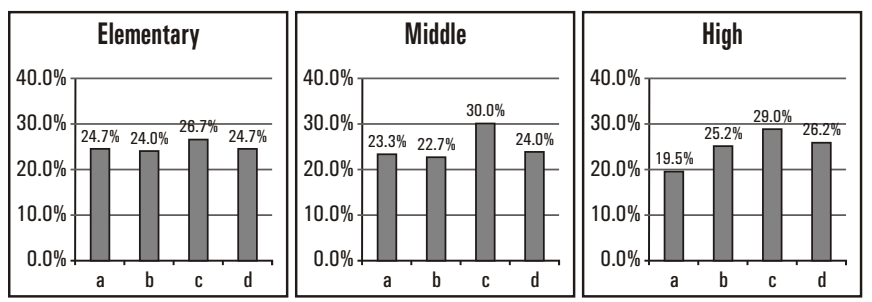

a) passion, b) self-fulfillment, c) source of income, d) everyday duty

Figure 2. The attitude of participants towards the performed job

Despite the positive attitude of the majority of the respondents to physical education at school, they observed numerous abnormalities concerning especially unattractive class content, insufficient sports and sanitary base, not enough outdoor activities, not enough dance in the classes, disregarding the teachers' proposals, ignoring the needs, interests and possibilities of the students in the process of planning and carrying out a class, inappropriate teachers' attitude towards the students and their own work. The most frequent charge against the teachers was the lack of contact with the youth based on respect, empathy, partnership, justice and commitment. Over a half of the schoolgirls were satisfied with the content of the classes. The girls suggested their own ideas concerning the content of the classes to the teachers, to which the majority of teachers were open. The most frequent reservation of the PE teachers was the lack of the balance between the number of boys and girls in a class, and the insufficiently equipped and modernized base.

In the opinion of the survey participants physical education serves the improvement of fitness (Fig. 3). 


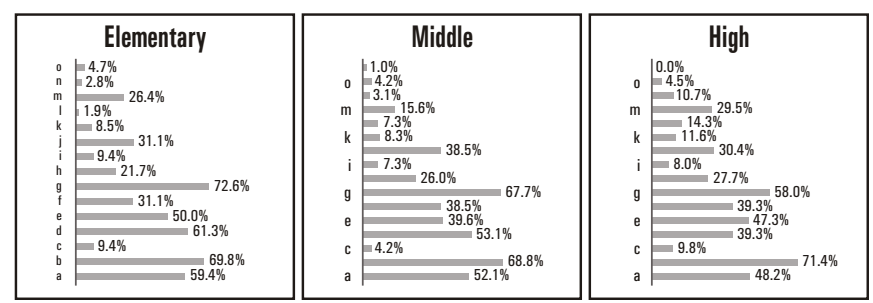

a) acquisition of dexterity,

b) improving physical fitness,

c) acquisition of knowledge,

d) participation in entertainment and play,

e) development of sports and recreational interests,

f) relaxation, rest, stress relief,

g) improvement of physical condition,

h) preparation to function in adult life

i) improvement of the appearance,

j) shaping of proper attitude towards the organism and its needs

k) shaping of co-existence with other people,

I) shaping of needs and habits of physical activity,

m) development of personality,

n) other or no answer.

Figure 3. Benefits ensuing from the participation in PE classes mentioned by the schoolgirls

In defining the term of physical culture the teachers highlighted the pro-health aspect, the development of personal fitness and getting to know the potential of the body. A decisive majority of the respondents perceived physical education in an incomplete way, as "shaping the motion abilities and fitness" (Fig. 4).

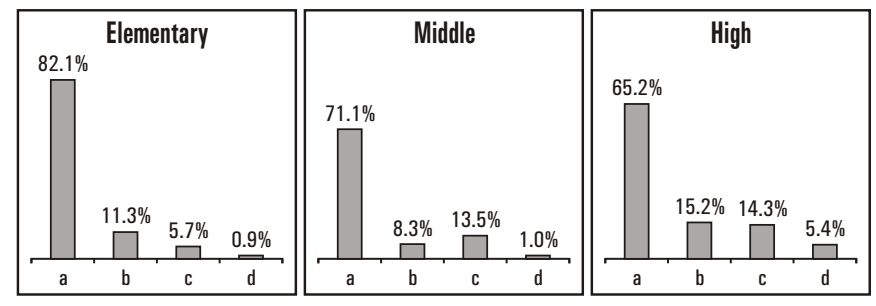

a) shaping of movement abilities and physical fitness,

b) shaping of physical, mental, emotional and intellectual sphere,

c) process aimed at the development of conscience regarding the care for health and fitness,

d) no answer

Figure 4. Perception of the term of physical culture by participants

In the opinion of the survey participants, the teacher assessing the attendance of the girls in PE classes should pay more attention to their attitude, commitment and progress. The assessment apart from health-fitness benefits was the main factor motivating the girls to participate actively in school physical education.

In the opinion of over half of the middle-school students and high-school students and one quarter of the elementary-school students the "Rhythm-Music-Dance" section was implemented in the PE curriculum (Fig. 5).

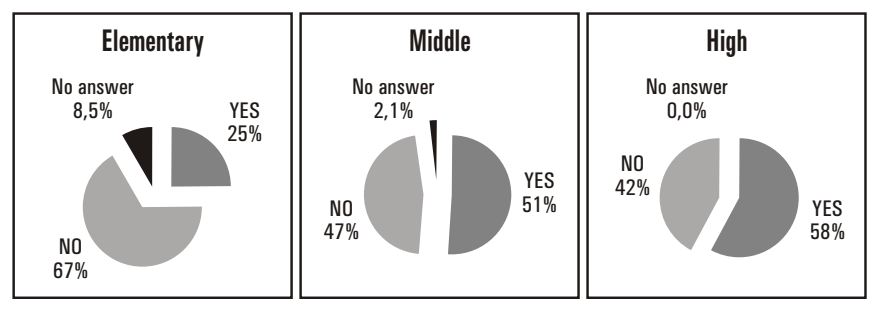

Figure 5. Realization of the "Rhythm-Music-Dance" section during PE classes in the opinion of the respondents

In elementary schools the section was realized in the form of a warm-up whereas, at further stages, as a separate lesson unit about once a month at middle schools and twice a month at high schools. The youngest girls evaded the question. According to the majority of the survey participants, at first stages of teaching the teachers were not enthusiastic about the classes, although all the schoolgirls would willingly attend them.

The middle-school and high-school teachers declared that they conducted classes with music at least a few times a year. At the elementary school $40.0 \%$ of the PE teachers did not implement the activities in the classes. It ensued mainly from the lack of proper vocational qualifications and a lack of interest from the students. The elementary-school and middle-school teachers implemented "Rhythm-Music-Dance" at the introductory stage of the class, or dedicated separate classes to realize the program. In middle schools it was applied as the main part of the class. Realizing the above-mention aspects of the curriculum in high schools, it was decided that the whole class should be devoted to it and later as the main or introductory part of the class. At middle schools and high schools among various dance forms the classes were dominated by elements of aerobics, amigo dances, and exercises improving the sense of rhythm, timing, pace and dynamics. The elementary-school teachers put special emphasis on the exercises that improve the sense of rhythm, timing, dynamics and later aerobics, folk dances, rhythm play, and gymnastics-dance exercises.

The most popular proposed curriculum solutions according to the schoolgirls were obligatory and extra classes, adjusted to the needs and interests of the schoolgirls, the possibility of creating individual teaching programs that take the needs of the students into account, the "sports voucher", the possibility of accumulating classes, and the realization of PE activities according to the profiles i.e. the sports, recreational, dance, tourism, and pro-health one.

The majority of the participating teachers preferred to work according to the principles of the 1999 reform. The teachers admitted that the division of teaching into two stages, namely obligatory and facultative stages, will have a positive effect on the process of teaching. Some PE teachers advocated the possibility of giving the students a choice of class type, with the exception of the youngest students. The PE teachers were in favor of increasing the weekly number of PE classes, and allowing for some self-assessment and self-control by the students in the process of physical education.

With the exception of the elementary-school students the vast majority of the survey participants declared a lack of participation in any exercise in their leisure time and a lack of their parents' physical activity.

Among the after school activities taken up by the girls the following should be mentioned: swimming, team games (especially volleyball, basketball and soccer), recreational forms (e.g. jogging, cycling and roller skating) dance, fitness exercises, gymnastics, horse-riding, and other activities done at the school sports club. 
The girls observed the need for permanent self-education by $\mathrm{PE}$ teachers whereas, as far as their own development was concerned, they did not display the proper attitude and a need to care for their own body. The vast majority of PE teachers understood the need for permanent self-education, the evidence of which were numerous sources of theoretical-practical knowledge used by them at work.

Ten most important guidelines on a perfect PE class for schoolgirls in the opinion of the respondents:

1. PE classes encourage students to participate through a friendly and pleasant atmosphere.

2. PE classes are attractive, consider the proposals, interests, needs and possibilities of schoolgirls.

3. PE classes enable active rest, pursuit of sports-recreational interests, improvement of fitness, acquisition of new motion abilities, relief of stress and emotions, give the feeling of joy, satisfaction and relaxation, and are a perfect form of play.

4. PE classes are held outdoors more often.

5. During PE classes students have access to sports and sanitary facilities. PE classes are most often held during the last period in the schedule, which allows the students to take a shower afterwards.

6. PE classes are held daily, also on Saturdays.

7. The tasks realized during a class are continued during extra classes that encourage and assist less athletic students.

8. During PE classes it is possible to take advantage of the sports clubs offer, and thanks to accumulating periods new, attractive forms of physical activity are realized.

9. When assessing the participation of schoolgirls in a PE class, the teacher takes into account their commitment and the attitude to the subject.

\section{Discussion}

An analysis of the material gathered revealed a number of conclusions that concur with the results found by other author' studies [13, 14, 15], in which (despite a prevalently positive attitude towards school physical education) the youth observed some abnormalities regarding the classes and the PE teachers. The reservations concerned the insufficient attractiveness of the classes, too few PE classes per week, not taking into account the needs and interests of the students, the lack of sanitary and sport facilities and an "unfair" assessment system. The basic fault found in the teachers was a disparaging and non-professional attitude towards the students and the work itself [13].

Inappropriate relations with the teacher, his disparaging attitude towards the class and the students and the fraternization of the teacher with the students are the main causes of the reluctance of the schoolgirls to participate in PE classes, which are perceived as not important enough. The authority of the teacher is lowered, which was confirmed by the study of other authors $[16,17,18,19,20]$. What was coincident with other studies $[13,15,21]$ were the interests of the respondents for whom the most attractive forms of physical activity were team games, swimming, tennis and recreational sports. The survey participants called for an increase in the dimension of dance forms.

An analysis of the material covering the attendance of schoolgirls in PE classes when they were not obligatory showed differences in the findings at Bakalarczyk and Skibińska [22]. The schoolgirls of Biała Podlaska elementary schools would, to a greater extent, attend the classes. The remaining schoolgirls declared attendance "from time to time" just like the schoolgirls of high schools in Górna and Skalik [21]. The girls from ele- mentary and middle schools declared systematic attendance in the classes. The leisure time spent by the schoolgirls from the middle and high schools were coincident with those of Bakalarczyk and Skibińska [22], whereas the girls from the elementary schools displayed more intense physical activity in their leisure time.

\section{Conclusions}

1. Although the vast majority of the schoolgirls and teachers observed abnormalities in the PE classes, they displayed a positive attitude towards the classes.

2. School physical education does not satisfy the needs and expectations of the respondents. The reservations of the schoolgirls concerned manly a lack of attractiveness of the classes, not taking into account their needs, possibilities, and interests, infrequent involvement of the schoolgirls in the process of planning and realization of the classes, insufficient sports and sanitary facilities, a lack of classes each week and moving them to the last period in the daily schedule.

3. Among the benefits derived from PE classes the girls most often mentioned health, the care for health, and the improvement of fitness.

4. The majority of the schoolgirls do not have sufficient knowledge of physical culture, as well as the need of lifelong physical self-education. The main source of the knowledge were the PE classes. Whereas the teachers displayed care for the constant improvement of their qualifications through participating in training courses of all kinds and using professional literature, magazines and the Internet.

5. The teachers underlined the importance of the subjective treatment of the students, high didactic-educational qualifications and openness to the student and the student's participation in creating the classes.

6. Despite the positive attitude of the schoolgirls to the "Rhythm-Music- Dance" section, in their opinion it was realized in every fourth elementary school and over a half of the middle and high schools. The classes were held once or twice a month, which did not meet the expectations and needs of the girls who, especially in elementary and middle schools, observed a great lack of enthusiasm on the part of the PE teachers. The majority of the teachers of middle and high schools declared inclusion of dance forms and exercises with music at least a few times each year, whereas as much as $40 \%$ of the elementary PE teachers did not include music-related activity in the classes.

7. The schoolgirls partially deepened their knowledge on the maturity process during PE classes. The teachers admitted that discussion of these issues was held spontaneously in the form of a talk or digression, most often when the conditions did not allow the teacher to conduct a normal class.

8. The schoolgirls responded very positively to the 2009 reform proposals, enabling the pursuit of their interests and involving the students in the process of planning and realizing the class. Although the majority of the teachers preferred to stick to the guidelines of the 1999 reform, a significant number of the teaching staff supported new solutions.

9. The schoolgirls listed their most attractive forms of outof-school activities i.e. team games, swimming, tennis, 
horse-riding, dances (the forms were offered by the school sports club), athletics (in professional sports clubs) and recreational sports. The teachers preferred team games, swimming, fitness exercises, strolls, jogging, nordic walking, climbing, cycling, roller skating and broadly understood recreation.

10. The teachers understand the need for permanent physical self-education and systematically engage in activities aimed at improving their competence. The schoolgirls demand it from the teachers whereas they do not themselves show the awareness of how to care for health and physical development.

\section{Literature}

1. Bielski, J. (2006). Humanistic aspects of physical education. Kultura Fizyczna 5-6, 16. [in Polish]

2. Wolny, B. (2006). Physical education in the reformed school. Lublin: KUL. [in Polish]

3. Derbich, J. (2000). Physical activity of children and their attitudes toward physical and health education. In W. Osiński \& R. Muszkieta (Eds.), Physical education and sport in scientific research (pp. 109-114). Poznań: AWF. [in Polish]

4. Szeklicki, R. \& Biernacki J. (2000). The attitude toward physical education of children and adolescents in Poland and their physical activity in leisure time. In W. Osiński \& R. Muszkieta (Eds.), Physical education and sport in scientific research (pp. 325-330). Poznań: AWF. [in Polish]

5. Pławińska, L. (2004). The reasons for reluctance to participate in physical education classes as given by the students of the Horticulture School in Szczecin. In W. Siwiński, R.D. Tauber \& E. Mucha-Szajek (Eds.), Hospitality, catering, tourism and recreation in the European integration process (pp. 197-208). Poznań: Wyższa Szkoła Hotelarstwa i Gastronomii. [in Polish]

6. Lech, P. (1998). Grief over the fourth hour. Lider 3, 19. [in Polish]

7. Bronikowski, M. (2002). Physical education classes yesterday and tomorrow. Wychowanie Fizyczne i Zdrowotne, 2, 23-24. [in Polish]

8. Makaruk, I. (1999). So that the girls would take a liking to physical activity. Lider 6, 22. [in Polish]

9. Bielski, J. (1996). Determinants of teacher effectiveness. Kielce: Wydawnictwo Wyższej Szkoły Pedagogicznej. [in Polish]

10. Madejski, E. \& Węglarz J. (2007). Selected issues of modern methodology of physical education. Guide for teachers and students. Kraków: Oficyna Wydawnicza „Impuls”. [in Polish]

11. Pańczyk, W. \& Warchoł K. (2006). Discussing theory, methodology and practice of contemporary physical education. Rzeszów: Wydawnictwo Uniwersytetu Rzeszowskiego. [in Polish]
12. Jankowska, K. (2001). The role of a physical education teacher in shaping student's personality. Wychowanie Fizyczne i Zdrowotne 4, 29-30. [in Polish]

13. Krawański, A. (1991). Physical education classess as seen by the students. Lider 3, 8-10. [in Polish]

14. Umiastowska, D. \& Godlewska T. (1999). Physical education as seen by the secondary schools students in Szczecin (benchmarking). Zeszyty Naukowe. Prace Instytutu Kultury Fizycznej/Uniwersytet Szczeciński 15, 133-143. [in Polish]

15. Janowska, M., Śleboda R. \& Muszkieta R. (1998). The effect of increased number of physical education classes on physical activity of the youth based on the studies conducted in selected elementary schools in Poznan. In D. Umiastowska (Ed.), Physical activity of people in all ages (pp. 63-67) Szczecin: Wydawnictwo Promocyjne ALBATROS. [in Polish]

16. Kucharska, E., Szewczak M. \& Pławińska L. (2003). The reasons for reluctance to participate in physical education classes as given by the students at different levels of education. In J. Jonkisz \& M. Lewandowski (Eds.), Education and training in the reformed school. Vol.4, (str. 131-136), Wrocławskie Towarzystwo Naukowe. [in Polish]

17. Napierała, M. (2003). Students' expectations towards physical education teacher. In R. Strzelczyk \& K. Karpowicz (Eds.), Physical education and sport in scientific research (pp. 155-156). Poznań: AWF. [in Polish]

18. Zieliński, J. (2001). The modern image of physical education teacher created by high school students. Przeglaqd Naukowy Instytutu Wychowania Fizycznego i Zdrowotnego Uniwersytetu Rzeszowskiego 4, 413-419. [in Polish]

19. Lewandowski, M. \& Jagusz M. (2003). Values and qualities required of a physical education teacher given by the female students of selected universities. In J. Jonkisz \& M. Lewandowski (Eds.), Education and training in the reformed school. Vol. 4 (pp. 245-255). Wrocławskie Towarzystwo Naukowe. [in Polish]

20. Kijo, P. (2003). The authority of a physical education teacher as seen by the students. In J. Jonkisz \& M. Lewandowski (Eds.), Education and training in the reformed school. Vol. 4 (pp. 271-276). Wrocławskie Towarzystwo Naukowe. [in Polish]

21. Górna, K. \& Skalik K. (2001). Female students' attitudes to physical education. In J. Ślężyński (Ed.), Effects of training and education in physical culture (pp. 233-239). Katowice: AWF. [in Polish]

22. Bakalarczyk, B. (2004). Values - the importance of physical education for high school students. Wychowanie Fizyczne i Zdrowotne 4, 32-35. [in Polish]

Submitted: February 14, 2012

Accepted: May 16, 2012 